\title{
INDO-PACIFIC TREATY SEBAGAI PERLUASAN KERJA SAMA INDONESIA DI BIDANG MARITIM
}

\section{Oleh: Putu Sukmadewi}

Program Studi Ilmu Hubungan Internasional

Fakultas Ilmu Sosial dan Ilmu Politik

Universitas Muhammadiyah Yogyakarta

itsdewi210896@gmail.com

\begin{abstract}
Abstrak:
Terpilihnya Joko Widodo sebagai Presiden Republik Indonesia pada Pemilu tahun 2014 menandakan perubahan orientasi politik Indonesia. Indonesia mengubah fokus kebijakan luar negerinya yang semula berorientasi ke darat serta aktif di kancah global menjadi berorientasi ke laut sekaligus membangun kembali budaya maritim yang sempat terabaikan melalui perjanjian Indo-Pasifik yang pertama kali digagas oleh Menteri Luar Negeri Indonesia, Marty Natalegawa. Tulisan ini menggunakan metode pengumpulan data kualitatif dan metode analisis data serta menggunakan konsep perubahan politik luar negeri dan determinan domestik, dimana suatu kebijakan disesuaikan dengan keadaan dalam negeri suatu negara dalam hal ini faktor geografis Indonesia yang terletak di persilangan samudera Hindia dan samudera Pasifik. Di dalam tulisan ini, terdapat temuan berupa faktor internal dan eksternal Indonesia menggagas perjanjian IndoPasifik serta lahirnya geopolitik Poros Maritim Dunia yang juga berkaitan dengan alasan Indonesia menggagas perjanjian tersebut.
\end{abstract}

Keyword: Perjanjian Indo-Pasifik, Indo-Pasifik, Poros Maritim Dunia, faktor internal, faktor eksternal

\section{PENDAHULUAN}

Dalam beberapa tahun terakhir ini, istilah Indo-Pasifik menjadi topik yang hangat dibicarakan karena dinilai memiliki peluang ekonomi sekaligus tantangan keamanan yang besar. Kawasan 
perairan ini meliputi Samudera Hindia, Samudera Pasifik, Benua Asia Daratan, Benua Australia, Asia Tenggara, serta negara-negara maju seperti Cina, Jepang, Korea Selatan, India, Australia, Amerika Serikat dan Kanada (Montratama, 2016). Sebagai negara-negara yang memiliki lokasi strategis karena posisinya berada di tengah-tengah kawasan Indo-Pasifik, kesepuluh negara ASEAN kini tengah memproses perancangan strategi agenda geopolitik. Konsep dari Indo-Pasifik dalam perjanjian Indo-Pasifik ini bertujuan untuk mempromosikan penyelesaian suatu permasalahan atau sengketa dengan cara damai dan saling mempercayai satu sama lain dengan tidak menggunakan kekuatan militer sebagai bentuk penyelesaian.

Tantangan paling utama dari konsep Indo-Pasifik adalah keberhasilan terwujudnya konsep sekaligus perjanjian ini bergantung pada sikap negara-negara yang terlibat. Langkah awal yang sudah dilakukan adalah pengusulan penanda-tanganan perjanjian oleh mantan Menteri Luar Negeri Indonesia, Marty Natalegawa pada bulan Mei 2013 (Ram, 2015).

Dalam pidatonya di East Asia Summit (EAS), Marty menekankan pentingnya negara-negara di kawasan Samudera Hindia dan Samudera Pasifik dengan Indonesia sebagai penghubung kedua samudera tersebut. ASEAN, termasuk Indonesia, hanya bisa aman dan stabil jika ada perdamaian dan kemakmuran di kawasan Indo-Pasifik. Marty mengingatkan para peserta bahwa pada tahun 2011, prinsip-prinsip deklarasi EAS untuk hubungan yang saling menguntungkan diadopsi oleh negara-negara kawasan Indo-Pasifik; dia akhirnya mengusulkan agar itu diubah menjadi "Perjanjian Persahabatan dan Kerjasama Indo-Pasifik" (Indo-Pacific Treaty of Friendship and Cooperation) untuk digunakan sebagai mekanisme untuk mengelola urusan keamanan regional. Namun tidak ada satu negara pun yang menunjukkan ketertarikan mereka terhadap perjanjian ini (Suryadinata, 2018).

Konsep Indo-Pasifik sederhananya adalah menyambungkan antara dua samudra dimana titik temunya berada di Indonesia. Hal ini membuat Indonesia harus menjadi peran utama dalam kerja sama geopolitik ini. Presiden menggarisbawahi bahwa kerja sama maritim merupakan kunci dalam pengembangan arsitektur kawasan Indo-Pasifik dan Indonesia memiliki komitmen kuat dalam meningkatkan kerja sama maritim baik melalui IORA maupun EAS. Indonesia mengharapkan kawasan Indo-Pasifik akan menjadi salah satu sumber utama pertumbuhan ekonomi, pusat perdagangan dan industri dunia. Konsep kawasan Indo-Pasifik juga disampaikan oleh Menteri Luar Negeri RI Retno Marsudi dalam Pidato Pers Tahunan di Kementerian Luar Negeri awal 
Januari lalu, Asosiasi Negara-negara Asia Tenggara (ASEAN) diharapkan menjadi inti untuk menggerakan strategi geopolitik Indo-Pasifik, dan Indonesia menjadi salah satu penggeraknya.

\section{PEMBAHASAN}

\section{Sejarah Konsep Indo-Pasifik}

Indo-Pasifik pertama kali dibahas oleh Perdana Menteri Jepang Shinzo Abe pada tahun 2007 dalam pidatonya ke parlemen India. Kemudian pada 16 Mei 2013, ketika Marty memberikan pidato di CSIS di Washington D.C. ia menggunakan istilah "wilayah Indo-Pasifik" secara eksplisit. Pendekatan Indo-Pasifik belum menjadi kebijakan luar negeri resmi Jepang ketika Abe bertemu Jokowi pada Januari 2017. Hanya setelah kembali ke Jepang barulah Kementrian Luar Negerinya mulai mengembangkan konsep dan secara resmi mengusulkannya pada April 2017 sebagai strategi "Indo-Pasifik Bebas dan Terbuka" yang sejak itu menjadi tulang punggung kebijakan keamanan Shinzo Abe. Perspektif Indo-Pasifik Marty berbeda dari Konsep Indo-Pasifik Shinzo Abe. Dalam perspektif Marty, Indo-Pasifik diartikan sebagai kawasan yang inklusif, dan tidak terbatas pada negara-negara demokratis barat. Ini mencakup Cina dan Rusia, dua negara yang menandatangani Deklarasi EAS di Bali.

Pada 9 Agustus 2018, barulah Menteri Luar Negeri RI Retno secara resmi mempresentasikan Konsep Kerjasama Indo-Pasifik Indonesia ke Pertemuan Tingkat Menteri 8 KTT Asia Timur. Retno dan diplomat Indonesia telah berkampanye untuk pengarahan dan melobi para peserta. Dalam sambutannya, Retno sangat menekankan pentingnya inisiatif Indonesia dalam pengaturan geopolitik saat ini di mana negara-negara di kawasan Indo-Pasifik memiliki potensi baru. Ia juga meyakinkan menteri EAS lainnya bahwa “...bukan untuk menciptakan mekanisme baru atau mengganti yang sudah ada, tetapi untuk meningkatkan kerja sama menggunakan mekanisme yang ada". Retno mengidentifikasi EAS sebagai platform ideal untuk mendorong kerjasama ekonomi di kawasan Indo-Pasifik. 


\section{Indo-Pasifik dalam Pandangan Indonesia}

Indonesia adalah salah satu negara di kawasan Indo-Pasifik yang telah mengalami peningkatan kemakmuran dan kesejahteraan yang cukup signifikan. Indonesia memiliki kepentingan untuk mempertahankan kondisi Indo-Pasifik yang tetap kondusif bagi pertumbuhan ekonomi dan keamanan nasionalnya, oleh karena itu Indonesia tidak bisa membiarkan situasi politik, ekonomi dan keamanan kawasan ditentukan semata-mata oleh negara-negara lain.

Perspektif Indo-Pasifik secara otomatis menempatkan Indonesia dan kawasan Asia Tenggara sebagai titik sentral yang menghubungkan kawasan Samudera Pasifik dan Samudera Hindia. Sebagai negara berkembang, Indonesia belum bisa semata mengandalkan kekuatan materialnya (ekonomi dan militer) untuk mempengaruhi dan membentuk kondisi kawasan yang kondusif dari sisi kepentingan nasional. Oleh karena itu, kebijakan kawasan ditekankan pada pengembangan tatanan, mekanisme, institusi kerja sama kawasan yang memungkinkan semua negara baik besar, menengah dan kecil mengelola kepentingan bersama. Suatu mekanisme kerja sama kawasan yang memungkinkan negara-negara untuk mengembangkan kerja sama yang saling menguntungkan dan membahas serta mengelola potensi konflik, ketidakpercayaan, kecurigaan dan berbagai bentuk ancaman lainnya.

Indo-Pacific Treaty bertujuan untuk meningkatkan saling percaya sekaligus mengesampingkan penggunaan kekerasan dalam menyelesaikan sengketa antara negara-negara di dalam kawasan. Dikatakan bahwa Indo-Pacific Treaty dikonsepkan untuk menjadi mekanisme pembangunan norma dan prinsip bagi sebuah kawasan yang senantiasa berubah dan diharapkan dengan IndoPacific Treaty ini akan bisa menciptakan keamanan bersama yang dihasilkan dengan tidak mengorbankan pihak-pihak lain yang ada di dalam kawasan tersebut.

Konsep kerja sama Indo-Pasifik yang dikembangkan Indonesia juga tidak bermaksud untuk menyaingi berbagai strategi Indo-Pasifik yang lain. Yang perlu menjadi perhatian Indonesia dan ASEAN adalah agar berbagai strategi Indo-Pasifik yang dikembangkan oleh negara-negara di kawasan harus dapat berkontribusi bagi pengembangan kawasan Indo-Pasifik yang damai, stabil, dan sejahtera. Pada intinya, kerja sama ASEAN dengan negara-negara mitra adalah untuk memastikan agar kekuatan-kekuatan luar kawasan Asia Tenggara menghormati dan mendukung upaya ASEAN menciptakan kawasan Asia Tenggara yang damai, stabil dan sejahtera. Indonesia juga sepenuhnya menyadari bahwa stabilitas kawasan Asia Tenggara sangat bergantung pada 
situasi dan kondisi di kawasan yang lebih luas yang mengelilingi kawasan Asia Tenggara, yaitu kawasan Indo-Pasifik.

\section{Implikasi Indo-Pasifik bagi Kerjasama Kawasan}

Dalam prosesnya, kawasan Indo-Pasifik akan menghadapi tantangan-tantangan yang beragam atau multi-faceted challenges yang tidak dapat dihindari (Natalegawa, 2013). Tantangan pertama adalah trust-deficit atau defisit kepercayaan. Tantangan yang dihadapi saat ini sangat mungkin untuk berkembang menjadi ancaman besar bahkan sampai menjadi konflik terbuka karena meningkatnya faktor ketidakpercayaan yang dapat meningkatkan tensi permasalahan tersebut. Cara penyelesaiannya adalah dengan membangun kepercayaan dan keyakinan, mengutamakan rasa saling menahan diri, membangun komunikasi. Komunikasi yang jelas dan terbuka antara negara-negara sekawasan diperlukan untuk menghindari konflik yang disebabkan oleh defsit kepercayaan antarnegara

Tantangan kedua adalah unresolved territorial claims atau sengketa wilayah yang belum terselesaikan. Terkait sengketa wilayah yang belum terselesaikan ini dibutuhkan komitmen dari pihak-pihak yang bersengketa wilayah untuk menghormati dan menyelesaikan sengketa secara damai sesuai dengan aturan-aturan tertentu yang telah disepakati agar menghindari kesalahan perhitungan atau munculnya krisis yang tidak diinginkan. Contoh dari masalah sengketa wilayah yang sangat krusial saat ini di kawasan Indo-Pasifk adalah sengketa wilayah di Laut Cina Selatan dan Laut Cina Timur.

Tantangan ketiga adalah managing the impact of change atau mengelola perubahan. Perubahan dan transformasi terjadi di seluruh kawasan Indo-Pasifik dalam bidang politik dan ekonomi yang memiliki dampak tidak hanya bagi internal negara tersebut tetapi juga negara-negara di sekitarnya. Sejalan dengan munculnya perubahan, maka muncul juga tantangan baru yang dapat dihadapi dengan cara menjalin hubungan kemitraan atau dengan cara berkompetisi. Terkait tantangan ketiga ini, dikarenakan perubahan dalam bidang ekonomi, keamanan dan politik di kawasan Indo-Pasifik tidak akan berakhir, maka hal ini yang menjadi inti dibutuhkannya sebuah perspektif baru dalam mengelola keamanan di kawasan Indo-Pasifik. 
Selain itu terdapat dua masalah dalam mewujudkan gagasan pembentukan Indo-Pacific Treaty. Pertama, tidak adanya dukungan dari negara-negara besar atas gagasan Indo-Pacific Treaty menjadi salah satu masalah dalam mewujudkan gagasan ini. Ram mengutip pernyataan dari Bandoro (Purnama, 2017) yang berpendapat bahwa tidak akan ada jaminan bahwa negara-negara besar akan menyetujui seperti yang diharapkan oleh Indonesia. Indonesia juga tidak mempunyai kemampuan untuk mendikte arah strategis negara-negara besar tersebut, sehingga kesuksesan gagasan Indo-Pacific Treaty ini masih bisa diperdebatkan.

Medcalf (Purnama, 2017) mengatakan bahwa permasalahan dalam mewujudkan gagasan IndoPacific Treaty secara tidak langsung memang terletak pada persetujuan negara-negara besar atas gagasan ini. Masalah ini juga terjadi pada TAC, yakni dimana negara-negara besar menyatakan menghormati institusi dan perjanjian yang ada, namun pada akhirnya mereka masih mencoba untuk menyelesaikan perselisihan mereka melalui paksaan dan pengaruh. Contohnya TAC tidak dapat menghentikan Cina dalam menggunakan paksaan dan ancaman kekuatan yang tersirat untuk mengubah status quo di Laut Cina Selatan. Tanpa dukungan dari negara-negara kuat di dalam Indo-Pacific Treaty, maka norma-norma yang dalam hal ini berupa harapan agar negara-negara tidak akan menggunakan kekuatan atau paksaan, tidak akan menjadi pencegah yang dibutuhkan. Banyak negara akan terus bergantung pada mitra aliansi tradisional mereka untuk perlindungan atau untuk memberikan keseimbangan kepada negara agresif lainnya.

Permasalahan kedua yakni tidak adanya blueprints yang menggambarkan dengan jelas bagaimana cara untuk mewujudkan gagasan Indo-Pacific Treaty ini. Hal tersebut sesuai yang dikemukakan oleh Liow bahwa tujuan mulia dari Indo-Pacific Treaty yang diusulkan oleh Indonesia ini tidak disertai dengan blueprints yang menggambarkan dengan jelas bagaimana cara untuk mewujudkannya. Tidak adanya blueprints menjadi masalah tersendiri dalam mewujudkan gagasan ini. Terlebih lagi dengan tidak adanya blueprint tersebut, Indonesia tidak memiliki dasar pegangan untuk meyakinkan negara-negara besar untuk memberikan dukungan dalam mewujudkan gagasan dan tujuan dari Indo-Pacific Treaty ini. 


\section{Keterbukaan Kawasan dalam Kerjasama Indo-Pasifik}

Meskipun menghadapi tantangan-tantangan yang beragam, konsep kerja sama Indo-Pasifik ini sesungguhnya sudah disepakati negara-negara ASEAN seperti yang dikatakan oleh Menteri Luar Negeri Retno dalam KTT ASEAN ke-33 di Suntec Convention Centre, Singapura (Menlu sebut konsep Indo-Pasifik disepakati ASEAN, 2018). Menurutnya, konsep Indo-Pasifik itu sendiri merupakan living document dalam artian sembari dijalankan, konsep itu juga diperkaya dengan ide-ide agar menjadi konsep yang lebih matang dan jelas. Yang menjadi tugas Indonesia selanjutnya sebagai penggagas dan negara-negara mitra selaku negara yang berkepentingan di kawasan Indo-Pasifik adalah mengeksekusi konsep tersebut menjadi tindakan yang nyata. Untuk mewujudkannya, perlu adanya keterbukaan kawasan agar rivalitas bisa ditekan menjadi kerja sama saling menguntungkan. Hal ini penting karena disamping menghasilkan kerja sama kawasan, jika berhasil dieksekusi, maka kedamaian, keamanan dan stabilitas kawasan juga semakin terjamin.

Beberapa negara kawasan Indo-Pasifik mulai menunjukkan keterbukaan mereka dengan menyetujui kerja sama maritim yang didorong oleh Indonesia. Sebagai contoh, Indonesia mengajak India, Australia dan Thailand untuk bekerja sama menjaga stabilitas kawasan serta pengembangan konsep Indo-Pasifik. Amerika dan Cina yang tidak luput dari perhatian karena memiliki kepentingannya sendiri di kawasan tersebut. Vijay Thakur Singh, ketua Delegasi India mengapresiasi Indonesia atas inisiatif pelaksanaan Pertemuan High Level Dialogue on IndoPacific Cooperation tanggal 20 Maret 2019 di Jakarta yang dinilai bermanfaat dan tepat waktu. Ia menegaskan pula komitmen India untuk menjaga stabilitas, perdamaian, dan kemakmuran di kawasan. Kerja sama yang saling menguntungkan senantiasa perlu diutamakan di tengah situasi geopolitik yang dinamis dan upaya negara besar memperebutkan pengaruh di kawasan (Indonesia Dorong Kerja Sama Maritim ASEAN-India di Kawasan Indo-Pasifik, 2019).

Sementara itu pada pertemuan ke-31 ASEAN-Australia Forum yang diselenggarakan di Malaysia, Jose Tavares selaku Dirjen Kerja Sama ASEAN menuturkan, "Berbagai kerja sama Indo-Pasifik yang ditawarkan oleh negara-negara besar memberikan kesempatan sekaligus tantangan. Secara alami, negara-negara besar akan senantiasa memperkuat pengaruhnya di kawasan dan siap untuk saling bersaing. ASEAN yang terletak di tengah dinamika geostrategis ini perlu terus menjaga stabilitas dan keamanan di kawasan. Menjadi kepentingan utama ASEAN untuk memastikan dinamika geostrategis saat ini tidak mengganggu stabilitas dan keamanan kawasan yang telah 
berkontribusi pada ksejahteraan masyarakat". Hal ini ditanggapi secara positif oleh Richard Maude, Ketua delegasi Australia yang mengapresiasi upaya bersama ASEAN dalam menentukan sikap di kawasan di tengah persaingan pengaruh major powers. High Level Dialogue on IndoPacific yang diselenggarakan oleh Indonesia juga dipandang sebagai langkah konkret dan tepat untuk meningkatkan rasa saling percaya. Australia juga menegaskan komitmennya untuk terus berkontribusi dalam menjaga stabilitas dan keamanan di Indo-Pasifik. Pertemuan juga membahas berbagai hal yang menjadi kepentingan bersama yaitu perkembangan dan arah ke depan kerja sama ASEAN-Australia antara lain di bidang pemberantasan terorisme, perdagangan dan penyelundupan manusia, kerja sama keamanan siber, kerja sama maritim, kerja sama ekonomi termasuk ASEAN-Australia-New Zealand Free Trade Area (AANZFTA) dan Regional Comprehensive Economic Partnership (RCEP), konektivitas, pendidikan, penanganan bencana, hubungan antar masyarakat dan lain sebagainya. Selain itu, pada Pertemuan telah pula dilakukan pertukaran pandangan mengenai isu-isu regional dan global lainnya.

Kerja sama ASEAN-Australia dalam bidang ekonomi telah berlangsung sangat kuat. AANZFTA yang menjadi dasar kerja sama ekonomi kedua pihak merupakan salah satu perjanjian perdagangan paling komprehensif antara ASEAN dengan Mitra Wicara. ASEAN-Australia Development Cooperation Program Phase II (AADCP II) dengan komitmen sebesar AUD 57 juta dan AANZFTA Economic Cooperation Support Program (AECSP) dengan komitmen sebesar AUD 32 juta turut menunjang penguatan kerja sama ekonomi ASEAN dan Australia. Dalam bidang sosial-budaya, pendidikan, pemuda, dan hubungan antar masyarakat menjadi area kerja sama utama. Dalam sepuluh tahun (2008-2018), Australia telah memberikan beasiswa kepada 16.855 pelajar ASEAN melalui program Australia Awards. Dan hingga akhir 2019 nanti, terdapat lebih dari 18.500 pelajar dan pemuda Australia yang akan belajar di ASEAN melalui program New Colombo Plan (Indonesia Ajak Australia Terus Jaga Stabilitas dan Keamanan di Indo-Pasifik, 2019)

Kemudian Indonesia-Thailand juga mendorong pengembangan konsep Indo-Pasifik ASEAN. Pemerintah Indonesia dan Thailand sepakat berkolaborasi dalam mendorong pengembangan konsep bersama ASEAN mengenai kerja sama Indo-Pasifik. Kesepakatan itu disampaikan oleh Menteri Luar Negeri RI Retno usai melakukan pertemuan bilateral dengan Menteri Luar Negeri Thailand Don Pramudwinai di Gedung Pancasila, Kementrian Luar Negeri di Jakarta. Thailand, 
sebagai ketua ASEAN, mendukung penuh atas pengembangan konsep Indo-Pasifik. Hal tersebut menghasilkan negara-negara anggota ASEAN telah sepakat bahwa perlu adanya pengembangan pandangan bersama tentang konsep Indo-Pasifik berdasarkan perspektif Indonesia yang menekankan sentralitas dan inklusifitas ASEAN (Indonesia-Thailand Dorong Pengembangan Konsep Indo-Pasifik ASEAN, 2019).

\section{Kebijakan Luar Negeri Inward-Looking Jokowi}

Konsep 'bebas-aktif' yang digagas oleh Mohammad Hatta sebagai pondasi kebijakan luar negeri Indonesia memiliki latar belakang dimana Mohammad Hatta tidak ingin Indonesia terseret dalam kontestasi Perang Dingin yang baru berkecamuk pada tahun 1947. Presiden-presiden terdahulu Indonesia memiliki sudut pandang yang berbeda mengenai konsep bebas-aktif tersebut. Di bawah Demokrasi Terpimpin, kebijakan luar negeri bebas-aktif Soekarno terlihat menjauh dan semakin ke "kiri". Pendapat ini diperkuat dengan Soekarno yang sering membela kelompok komunis. Sebaliknya pada era Soeharto, beliau merubah kecenderungan kebijakan luar negeri menjadi semakin ke "kanan". Ide dan gagasan yang berorientasi pada pembangunan menjadi jargon utama Soeharto ketika memimpin Indonesia. Pada era BJ Habibie yang memerintah di era transisi, beliau lebih fokus dengan permasalahan dalam negeri dengan 'membereskan' sisa-sisa kekacauan di era Soeharto. Kebijakan luar negeri Indonesia yang digagas oleh Gus Dur lebih berfokus pada peningkatan citra Indonesia di mata internasional. Sementara itu, Megawati lebih berfokus pada pembangunan ekonomi dan stabilitas kawasan. Hal tersebut mengakibatkan ASEAN kembali menjadi bagian penting dalam kerangka kebijakan luar negeri Indonesia yang kurang mendapat perhatian pada era Presiden sebelumnya yaitu Gus Dur. Di bawah Presiden Susilo Bambang Yudhoyono, kebijakan luar negeri Indonesia di atas jalur yang semakin stabil. Konsep "many

friends-zero enemy" menjadi jargon utama kebijakan luar negeri yang digagas Susilo Bambang Yudhoyono (Maksum, 2015)

Jika selama ini Presiden Indonesia setelah era Soekarno lebih memprioritaskan kebijakan ke luar (outward looking) serta membuat Indonesia aktif di panggung internasional, maka Presiden Joko Widodo berinisiatif untuk memperbaiki kondisi ekonomi Indonesia melalui pemanfaatan aspek maritim dan lebih berfokus dengan kebijakan ke dalam (inward looking) demi membangun pondasi negara yang kuat. Sayangnya sebagai bangsa maritim yang secara geografis terletak di 
tengah-tengah Samudera Hindia dan Samudera Pasifik, pada periode pemerintahan Indonesia sebelumnya perhatian terhadap aspek maritim cenderung terabaikan. Ini terlihat dari era orde lama dan orde baru yang lebih memprioritaskan pembangunan ekonomi non-maritim. Pemerintahan era Joko Widodo ini dianggap sebagai turning point dengan membangkitkan kembali identitas Indonesia sebagai bangsa maritim melalui kebijakan inward looking-nya. Selain itu, isu eksternal non-tradisional seperti masalah perbatasan, masalah lingkungan, pekerja migran serta penyelundupan manusia yang seringkali menjadi isu maritim yang sebelumnya tidak menjadi perhatian presiden-presiden terdahulu mulai terlihat. Faktor eksternal inilah yang mendorong Indonesia dalam menyesuaikan kebijakan luar negerinya dengan permasalahan yang ada dalam rangka melindungi warga negaranya sekaligus membangun hubungan yang baik dengan negaranegara kawasan serta memperkuat Indonesia sebagai bangsa maritim (Wirasenjaya, 2018)

Dengan berdasarkan pada prinsip politik luar negeri yang bebas aktif dan amanat konstitusi, maka misi atau tujuan kebijakan luar negeri Jokowi adalah sebagai berikut; (1) Mengedepankan identitas sebagai negara kepulauan dalam pelaksanaan diplomasi dan membangun kerjasama internasional; (2) Meningkatkan peran Indonesia secara global melalui diplomasi middle power yang menempatkan Indonesia sebagai kekuatan regional dan kekuatan global dengan memberikan prioritas kepada permasalahan yang secara langsung berkaitan dengan kepentingan bangsa dan negara Indonesia; (3) Memperluas jangkauan keterlibatan regional di kawasan Indo-Pasifik, dan; (4) Merumuskan dan melaksanakan politik luar negeri yang melibatkan peran, aspirasi dan keterlibatan masyarakat.

\section{Kebijakan Kelautan: Menuju Poros Maritim Dunia}

Sebagai negara yang menyandang predikat Negara Kepulauan Maritim dengan 13.500 pulau dan wilayah laut yang memiliki panjang sekitar 3.000 mil serta posisi perdagangan strategis Indonesia yang berada di antara 2 samudera serta 2 benua, Indonesia memiliki visi sebagai Poros Maritim Dunia dimana pemerintah memiliki agenda terkait dengan visi tersebut diantaranya adalah pembangunan kembali budaya maritim yang sempat terabaikan, pengelolaan sumber daya maritim, pembangunan infrastruktur dan konektivitas maritim, diplomasi dan pertahanan keamanan maritim. Seperti yang sudah diketahui bahwa kekayaan sumber daya kelautan dari laut yang mengelilingi Indonesia berpotensi sangat besar untuk pengembangan ekonomi nasional 
dalam rangka mewujudkan cita-cita Indonesia sebagai Poros Maritim Dunia. Pengaturan dan pemanfaatan laut harus dilaksanakan secara teratur agar terhindar dari resiko kerusakan populasi, habitat dan ekosistem. Sebagai negara berkembang, Indonesia butuh menjalin dan memperkuat kerjasama bersama negara maju untuk pengembangan teknologi eksplorasi dan eksploitasi sumber daya laut. Selain itu, perlu bagi Indonesia untuk memprioritaskan peningkatan keselamatan dan keamanan daerah laut.

Untuk menjadi negara pemimpin selaku penggagas kerja sama Indo-Pasifik, Indonesia harus memulainya dari pemanfaatan laut yang selama ini tidak menjadi perhatian. Dari gambaran mengenai betapa strategisnya Indonesia beserta lautnya, ini berdampak pada aspek perekonomian. Zona Ekonomi Ekslusif Indonesia seluas 2.400.000 kilometer persegi serta potensi laut Indonesia yang kaya akan sumber daya seharusnya menjadi penunjang bagi Indonesia agar menjadi negara yang lebih sejahtera dan makmur. Indonesia memiliki Zona Ekonomi Ekslusif yang cukup luas serta memiliki banyak sektor yang dapat digali potensinya, yaitu antara lain sektor perikanan budidaya, sektor pengolahan perikanan, eksplorasi dan eksploitasi sumber daya energi laut lepas, dan sektor perikanan. Namun faktanya, beragam sektor tersebut hingga saat ini belum banyak dieksplorasi sehingga membuka peluang besar bagi kapal-kapal asing untuk mengeruk kekayaan laut Indonesia secara ilegal. Hal ini dibuktikan dengan tertangkapnya kapal-kapal dengan bendera asing yang akhir-akhir ini kerap diberitakan oleh media sekaligus membuktikan bahwa kekayaan laut Indonesia sangat banyak dan belum bisa dimanfaatkan untuk peningkatan kesejahteraan masyarakat. Untuk saat ini Indonesia belum dapat memaksimalkan potensi ekonomi laut. Permasalahannya adalah kurang maksimalnya pemanfaatan disebabkan oleh Indonesia yang belum didukung oleh teknologi yang canggih.

Selain itu, alasan laut dianggap sektor penting bagi Jokowi dikarenakan laut menyumbang sekitar 22,5\% dari produk domestik bruto (PDB). Persentase yang cukup tinggi itu membuat sektor kelautan menjadi penting dan membutuhkan perhatian khusus. Namun dalam perjalanannya, ada beberapa masalah dan tantangan yang tidak dapat dihindari. Dimulai dari identifikasi dan pemanfaatan SDL, manajemen birokrasi, revisi peraturan perundang-undangan, serta upaya meningkatkan investasi. Identifikasi harus dilakukan untuk memudahkan pemerintah dan pemangku kebijakan guna menghasilkan solusi yang solutif dan relevan. Untuk menjalankan perekonomian yang berbasis maritim, maka lahirlah undang-undang nomor 32 Tahun 2014 yang 
memiliki 13 bab. Beberapa implikasi lahirnya undang-undang ini adalah, pertama, lahirnya Badan Keamanan Laut yang disingkat dengan Bakamla sebagai implikasi dari Pasal 59. Bakamla merupakan badan yang menangani tentang keamanan dan penegakan hukum di laut yang berada langsung di bawah perintah Presiden. Kedua, pasal 30 memiliki implikasi bahwa pemerintah memiliki kewajiban mengembangkan dan meningkatkan penggunaan angkutan perairan dalam rangka konektivitas antar wilayah, pemerintah harus melaksanakan kebijakan pengembangan armada nasional dalam laut, pemerintah mengatur kebijakan sumber pembiayaan dan perpajakan yang berpihak pada kemudahan pengembangan sarana prasarana laut, dan pemerintah memfasilitasi sumber pembiayaan usaha perhubungan laut. Ketiga, pasal 58 memiliki implikasi terbentuknya sistem pertahanan laut.

\section{Perubahan Politik Luar Negeri: Faktor Internal Dan Eksternal Indonesia Menggagas Perjanjian Indo-Pasifik}

Setiap era pemerintahan masing-masing Presiden di Indonesia memiliki perbedaan terhadap penerapan poltik luar negeri yang diterapkan di Indonesia dan pemahaman yang berbeda mengenai doktrin bebas-aktif. Di era Presiden Soekarno, misalnya, kebijakan luar negeri lebih terfokus pada upaya mempertahankan kemerdekaan, sedangkan selama Presiden Soeharto fokus pada pembangunan ekonomi dengan mencari mitra di luar negeri. Diikuti oleh era reformasi dimana sistem diplomasi yang lebih demokratis juga meluas karena tuntutan pemegang kedaulatan rakyat sendiri. Kemudian pada era Presiden Susilo Bambang Yudhoyono (SBY) dimana poltik luar negeri Indonesia di tampilkan dengan sosok politik yang high profile. Darmansjah Djumala membuat perbandingan antara kebijakan luar negeri Jokowi dan praktik Susilo Bambang Yudhoyono (SBY). Perbandingan didasarkan pada empat indikator, yaitu masalah operasional, orientasi, pendekatan dan prioritas. Dalam hal orientasi, SBY memprioritaskan internasionalisme. Kebijakan luar negeri SBY moderat dan lebih fokus pada penanganan masalah politik dan demokrasi. Sementara itu, Jokowi menjadikan kepentingan publik sebagai orientasi utama. Djumala menambahkan, kebijakan Jokowi lebih memprioritaskan masalah ekonomi kerakyatan daripada masalah politik.

Di bawah pemerintahan pertama Yudhoyono, ia menempatkan keterlibatan internasional sebagai prioritas utama kebijakan luar negeri Indonesia. Menambah teman dan mengurangi musuh, Yudhoyono telah mencoba untuk meningkatkan peran Jakarta di tingkat regional dan global. Ia 
mengarahkan kebijakan luar negeri Indonesia ke orientasi luar yang didasarkan pada nilai-nilai demokrasi. Hal ini dapat dilihat dalam pidato kebijakan luar negeri pertamanya sejak ia terpilih sebagai Presiden. Yudhoyono memiliki pola politik luar negeri dimana ia mengedepankan citra Indonesia yang bersifat merangkul banyak pihak dalam kerja sama yang saling menguntungkan melalui diplomasi internasional. Menurutnya, langkah tersebut dapat memberikan tempat bagi Indonesia di dunia internasional sehingga Indonesia dapat turut serta menentukan dan berkontribusi untuk membuat tatanan global (Widiatmaja \& Albab, 2019).

Di bawah kepemimpinan Jokowi, Indonesia mencetuskan "diplomasi membumi” atau biasa disebut dengan sebutan "diplomasi pro-rakyat" dimana Indonesia akan lebih fokus pada isu-isu dalam negeri. Kebijakan ini akan lebih condong pada mengurusi masalah-masalah domestik dibandingkan pemerintahan sebelumnya, Susilo Bambang Yudhoyono, yang menekankan pada penguatan peran Indonesia di kawasan dengan slogan "ribuan teman, nol musuh". Pergeseran kearah domestik ini telah menyita perhatian dari banyak pengamat terkait dengan menurunnya keterlibatan Indonesia di panggung internasional. Jokowi dengan diplomasi pro-rakyatnya, membuat Indonesia berhasil memperoleh perhatian yang besar terkait cara Indonesia menyikapi isu-isu luar negeri.

Dalam kesempatan lain Retno juga menekankan tiga arah penting sebagai turunan dari kebijakan luar negeri pro-rakyat. Pertama, memperkuat ekonomi Indonesia melalui kegiatan diplomasi. Untuk mencapainya, harus ada hubungan timbal balik antara kebijakan luar negeri dan kebijakan pembangunan ekonomi. Kedua, aktif dalam melakukan mekanisme bilateral sebagai instrumen diplomatik daripada forum multilateral. Ketiga, memungkinkan pakar hubungan internasional untuk lebih aktif dalam mempromosikan keunggulan kompetitif Indonesia secara ekonomi. Para diplomat sangat diharapkan untuk memainkan hal-hal yang diperlukan untuk mengintegrasikan Indonesia dengan pasar dunia.

Namun demikian, itu tidak berarti bahwa Jokowi mengabaikan kehadiran Indonesia di panggung internasional. Mempertahankan keberadaan Indonesia di panggung internasional masih diperlukan untuk mendukung manfaat ekonomi nasional-domestik. Diplomasi pro-rakyat juga tidak bisa dilepaskan dari pertimbangan kedekatan geografis. Lingkaran pertama ditempatkan oleh ASEAN sebagai landasan kebijakan luar negeri Indonesia. Negara-negara di Asia Timur mengikuti tahap kedua dan tahap ketiga adalah negara-negara tetangga di kawasan Indo Pasifik. Di bawah kerangka 
kerja ini fokus diplomasi pro-rakyat adalah untuk memenuhi kebutuhan domestik, diplomasi prorakyat harus melibatkan pemain strategis di setiap tahap di bawah arsitektur regional yang inklusif.

Terdapat setidaknya ada empat faktor terkait dengan alasan Indonesia menggagas perjanjian IndoPasifik, yaitu: Pertama, memperkuat ekonomi Indonesia melalui kegiatan diplomasi. Kegiatan diplomasi ini dapat berupa kerja sama antar-negara kawasan khususnya di bidang ekonomi maritim sebagai syarat untuk menuju Indonesia yang lebih sejahtera dan makmur. Kedua, mengembalikan identitas Indonesia sebagai negara maritim. Hal ini dapat diwujudkan dengan pemanfaatan secara maksimal serta pengelolaan kekayaan yang tepat pada sumber daya yang tersebar luas di lautan demi mencukupi kebutuhan rakyat. Ketiga, menjaga keamanan kawasan Indo-Pasifik selaku penggagas perjanjian Indo-Pasifik dan sebagai big brother bagi ASEAN. Sejalan dengan orientasi kebijakan luar negeri ke dalam yang digagas oleh Presiden Jokowi, keamanan kawasan dapat diwujudkan dengan menunjukkan sikap saling percaya serta menenggelamkan kapal-kapal asing illegal yang menjarah kekayaan sumber daya laut di kawasan. Keempat, meredam konflik yang berpotensi akan mengancam keamanan kawasan dengan cara menjalin kerja sama karena kerja sama merupakan salah satu cara untuk menghasilkan hubungan yang baik antar-negara sekaligus meminimalisir kemungkinan terjadinya konflik.

\section{Determinan Domestik: Munculnya Gagasan Poros Maritim Dunia}

Menilik dari segi sejarah, yang pertama kali memanfaatkan laut untuk mengembangkan serta menyejahterakan Indonesia adalah presiden pertama Indonesia, Soekarno. Beliau jugalah yang menetapkan Indonesia sebagai negara kepulauan melalui deklarasi Djoeanda pada tanggal 13 Desember 1957. Hal ini dilakukan dengan maksud untuk membentuk jati diri bangsa sekaligus sebagai politik luar negeri Indonesia pada masa pemerintahannya. Kemudian pada tahun 2014, Jokowi terpilih menjadi presiden Indonesia. Beliau memiliki program yakni menjadikan Indonesia sebagai Poros Maritim Dunia yang juga merupakan wacana Presiden Jokowi serta salah satu kebijakan luar negeri dari Indonesia pada masa pemerintahannya.

Ini menjadikan laut sebagai basis kehidupan sehari-hari rakyat Indonesia dari Sabang sampai Merauke, dan dari Talaud sampai Rote, sekaligus masa depan mereka. Konektivitas laut merupakan kunci untuk mencapai kemajuan dan meraih cita-cita mewujudkan kesejahteraan bagi 
seluruh rakyat di Indonesia. Dari sudut pandang geopolitik, Poros Maritim Dunia muncul dan dikampanyekan sebagai strategi pemerintah dengan menjadikan sektor maritim sebagai panduan sekaligus tujuan pembangunan kabinet kerjanya. Penjabaran yang lebih luas dari konsep Poros Maritim Dunia, ini mencakup pengembangan infrastruktur pelabuhan, kehadiran kapal-kapal dan fasilitas asing di berbagai pelabuhan Indonesia, serta konektivitas wilayah melalui jalur transportasi laut yang bebas hambatan (tol laut) dari dan menuju jalur pelayaran internasional.

Poros Maritim Dunia memiliki dua konsep di dalamnya yaitu konsep geografi pada kata maritim dan politik pada kata poros dan dunia. Grygiel (Yani dan Montratama, 2015) mengemukakan bahwa Poros Maritim Dunia lahir atas respons Indonesia mengenai dinamika geopolitik yang terjadi di Indo-Pasifik dimana posisi geografi Indonesia berada tepat di tengah-tengah IndoPasifik. Dengan membangkitkan kembali budaya maritim, bangsa Indonesia sudah semestinya meninggalkan budaya lamanya yang lebih berorientasi ke darat agar dapat menjadi sebuah negara maritim. Hanya melalui kehadiran kebijakan Poros Maritim Dunia ini pula, Indonesia baru bisa memiliki kekuatan laut. Sedangkan dengan dari segi ekonomi maritim, melalui jalur pelayaran internasional dan pelabuhan-pelabuhan, Indonesia dapat membangun basis ekonomi rakyatnya. Kebijakan Poros Maritim Dunia yang diimplementasikan Presiden Jokowi berkaitan dengan doktrin Trisakti Presiden Soekarno, yakni kemandirian di bidang politik, ekonomi, dan sosialbudaya.

Presiden Jokowi menekankan ada 2 hal terkait dengan strategi Poros Maritim Dunia. Yang pertama, memajukan perekonomian maritim Indonesia melalui pembangunan ekonomi lokal dengan mendukung terwujudnya infrastruktur. Salah satu rencana pembangunan dalam menunjang poros ekonomi maritim adalah pembangunan tol laut. Ini sangat berguna untuk menghubungkan 17.504 pulau yang tentunya membutuhkan waktu yang tidak singkat untuk mengintegrasikan banyak pulau tersebut dalam kegiatan ekonomi. Dengan tol laut, diharapkan kegiatan ekonomi berlangsung dengan baik. Kedua, Jokowi ingin mempertegas bahwa identitas bangsa Indonesia adalah identitas maritim. Gagasan ini kemudian dikembangan menjadi doktrin keamanan maritim, bahwa Indonesia harus berdaulat di perairan lautnya dengan tegas menghukum pelanggaran terhadap kapal asing yang masuk ke perairan Indonesia secara ilegal dengan menenggelamkan kapal tersebut. 
Terdapat setidaknya tiga penafsiran mengenai Poros Maritim Dunia, terutama penafsiran dari kata 'poros' (Yani \& Montratama, 2015). Pertama, kelompok yang memaknai poros sebagai pusat atau sumbu dalam artian memaknai Poros Maritim Dunia sebagai visi Indonesia menjadikan laut sebagai pusat aktivitas kelautan dunia. Kelompok ini menamainya Global Maritime Fulcrum. Kelompok kedua memaknai poros seperti apa yang dulu disebut poros Beijing-Pyongyang-Jakarta. Dalam sudut pandang kelompok kedua, ada hubungan yang ingin dibangun Indonesia dengan negara (kekuatan) lain di kawasan yang dapat membawa Indonesia mewujudkan kepentingan nasionalnya. Kelompok ini menamainya Global Maritime Axis. Kelompok terakhir, yaitu kelompok ketiga yang memaknai poros maritim sebagai jalur pelayaran maritim, sehingga maksud dari Poros Maritim Dunia adalah visi Indonesia untuk menguasai jalur pelayaran maritim dunia. Oleh kelompok ketiga, mereka menamainya Global Maritime Nexus. Sebuah kebijakan dibuat dengan mempertimbangkan kondisi geografis suatu negara, maka dari itu sejalan dengan argumen determinan domestik yang mengacu pada kondisi geografi suatu negara serta memiliki argumen bahwasannya suatu kebijakan dipengaruhi oleh kondisi geografi suatu negara, tulisan ini menafsirkan Poros Maritim Dunia ke dalam kelompok pertama, yaitu Poros Maritim Dunia sebagai geopolitik sekaligus menjadikan laut sebagai pusat aktivitas Indonesia.

\section{Kepentingan Negara Besar}

Ada empat peristiwa penting yang terjadi di dunia saat ini, yaitu: Indo-Pasifik (India dan Jepang) di tahun 2007, Rebalancing towards Asia (Amerika Serikat dan Indonesia) di tahun 2011, Jalur Sutra Maritim (Tiongkok) di tahun 2013, dan Poros Maritim Dunia (Indonesia) di tahun 2014. Persaingan politik antar negara besar seperti Amerika Serikat, Cina, India dan Jepang memiliki kepentingan untuk memperebutkan akses kendali di rute pelayaran samudera Hindia dan samudera Pasifik atas 3 hal: jalur pelayaran, pasar, dan sumber daya alam di laut. Negara-negara besar itu juga memiliki kekuatan yang cukup besar untuk bisa bersaing di kancah regional dan global dari segi kekuatan militer, kekuatan finansial, dan penguasaan teknologi.

Jepang mempopulerkan istilah Indo-Pasifik melalui konsep Confluence of the Two Seas yang ditawarkan ke India sekaligus memiliki maksud atas keterbukaan jalur transportasi bagi orangorang, barang, modal dan pengetahuan dari Jepang ke India dan sebaliknya, serta meningkatkan hubungan dagang. Sedangkan untuk geopolitik AS Rebalancing atau Pivot to Asia Pacific 
dianggap sebagai bentuk strategi terhadap Cina yang kekuatannya semakin besar untuk dapat meningkatkan pengaruhnya di kawasan Indo-Pasifik. Australia, India, dan Jepang merupakan tiga negara yang berkepentingan di kawasan Asia Tenggara yang sering melibatkan diri di perpolitikan Asia Tenggara meskipun kekuatan mereka tidak sebesar Amerika Serikat atau Cina. Asia Tenggara dalam sudut pandang australia merupakan 'pintu gerbang' yang mana untuk dapat menyerang Australia, mereka harus menguasai Asia Tenggara terlebih dahulu.

Lalu kawasan Asia Tenggara dalam sudut pandang India, kawasan tersebut memiliki potensi besar dalam hal kerja sama ekonomi sekaligus pintu masuk ancaman bagi India yaitu Cina. Ini menyababkan India harus selalu memantau perkembangan politik di Asia Tenggara. Dari sudut pandang geopolitik India, mereka dituntut untuk memiliki kekuatan tambahan dalam menghadapi Tiongkok dan Pakistan dalam isu sengketa perbatasan oleh sebab itu India menunjukkan sikap kemitraannya terhadap Amerika Serikat di bidang pertahanan.

Berdasarkan pemaparan diatas mengenai geopolitik yang dilakukan oleh lima negara besar yaitu Amerika Serikat, Cina, India, Jepang dan Australia, terdapat tiga kepentingan yang berusaha diamankan oleh kelima negara tersebut: Pertama, rute pelayaran; Kedua, akses ke pasar; dan Ketiga, akses ke sumber daya di kawasan Indo-Pasifik. Posisi Indonesia yang terletak tepat di tengah-tengah kawasan Indo-Pasifik membuat Indonesia harus memanfaatkan kawasan perairan sebaik-baiknya sekaligus menghadapi persaingan antar Cina dan Amerika Serikat. Di satu sisi, Indonesia menginginkan Cina untuk terus berinvestasi pada Indonesia dalam hal pembangunan infrastruktur serta memperkuat industri dalam negeri yang berpotensi dapat membuka lapangan pekerjaan. Oleh sebab itu Indonesia berinisiatif untuk membentuk hubungan yang baik dengan Cina. Di sisi lain terlibatnya Cina di kawasan Asia Tenggara membuat stabilitas kawasan terancam, terlihat dari Cina yang menolak usulan Filipina untuk memasukkan sengketa Laut Cina Selatan ke dalam Joint Communique ASEAN.

\section{Implikasi Kebijakan Poros Maritim Dunia}

Presiden Jokowi dalam kunjungannya ke mancanegara serta memanfaatkan forum internasional untuk mempromosikan agenda Poros Maritim Dunia itu menuai respons yang antusias negaranegara lain terutama negara-negara besar dari dalam maupun luar kawasan seperti Cina, Amerika 
Serikat, Australia dan bahkan dari sesama negara ASEAN. Sebagai contoh, Cina menunjukkan antusiasme mereka dengan melakukan investasi dalam hal pembangunan infrastruktur laut khususnya tol laut sebesar 2 milyar dolar AS. Sejalan dengan kepentingan Cina yang ingin mengembangkan pelabuhan untuk mewujudkan proyek Jalur Sutra Maritim, Cina menawarkan proyek berupa pengembangan pelabuhan Malahayati, Belawan, Jambi, Tanjung Perak, dan Tanjung Mas.

Dengan sifat Cina yang berusaha mengambil kesempatan di setiap celah kebijakan luar negeri Indonesia , mereka juga mengajukan agar proposal Jalur Sutra Maritim digabungkan dengan kebijakan Poros Maritim Dunia milik Indonesia. Namun Indonesia justru merasa bahwa dua kebijakan itu tidak bisa digabungkan karena berpotensi mengancam baik keamanan maritim maupun secara ekonomi akibat pencurian sumber daya laut. Hal ini dibuktikan dengan ditemukannya nelayan-nelayan Cina yang menggunakan bendera Indonesia di kapal-kapalnya. Ditambah, Cina berusaha mengalihkan perhatian Indonesia dari fokus keamanan maritimnyadalam hal ini berupa penenggelaman kapal Cina yang melakukan illegal fishing — dengan berdalih bahwa baik pihak Indonesia maupun pihak Cina harus lebih memprioritaskan pembangunan di sektor maritim. Maka dari itu, adalah penting bagi Indonesia untuk dapat mengembangkan kerjasamanya dan tidak hanya terpaku dengan satu negara saja agar tidak terikat maupun dikontrol oleh kepentingan negara-negara besar dalam menjalankan sekaligus meraih manfaat dari agenda Poros Maritim Dunia.

Sementara itu Amerika Serikat menyalurkan dana sebesar 33 juta dolar AS melalui Dubes Robert O'Blake dalam program Indonesia-America Partnership for Marine and Fisheries Vocational Education guna membantu sektor maritim Indonesia terutama dalam hal pengawasan serta penangkapan ikan secara ilegal. Sebelumnya dana sebesar 35 juta dolar AS disalurkan oleh pemerintah Amerika Serikat yang mengatasnamakan kepedulian mereka terhadap konservasi laut Indonesia yang kaya akan sumber daya alam.

Dengan Cina yang mencari celah di kebijakan Poros Maritim Dunia Indonesia dan kepentingan Jalur Sutra Maritimnya serta Amerika Serikat yang juga tidak mau kalah dan 'membantu' Indonesia dengan investasi di sektor maritim, ini menunjukkan bahwa mereka memiliki kepentingannya sendiri dan mencoba menanamkannya pada Indonesia. Cina sebagai negara adidaya baru pasca era perang dingin serta Amerika Serikat yang ingin mengembalikan 
hegemoninya di kawasan Asia Tenggara, sama-sama merespons atas infrastruktur Indonesia. Sementara negara-negara lain kini tengah menghadapi pertumbuhan ekonomi yang stagnan serta permasalahan dalam negeri maupun luar negerinya dan oleh sebab itu terdapat keterbatasan dalam bantuan berupa hal biaya.

Selanjutnya yang tidak kalah pentingnya yaitu respons dari sesama negara ASEAN. Sebagai contoh, Vietnam, menunjukkan reaksinya terhadap sikap tegas Jokowi setelah banyak kapal dan nelayannya ditangkap akibat melakukan kegiatan illegal fishing di sekitar perairan Indonesia. Mereka merasa keberatan dan tidak nyaman dengan sikap keras yang dilakukan pemerintah Indonesia terhadap kapal dan nelayan Vietnam yang tertangkap. Sementara itu, Filipina menilai kebijakan pemerintah Indonesia yang melakukan penembakan serta penenggelaman kapal terlalu berlebihan. Bahkan, Presiden Aquino menyambut baik MOU dalam hal memerangi pencurian ikan bersama-sama. Lain halnya dengan respons Thailand, mereka justru menunjukkan reaksi negatif. Praporn Ekouru selaku Ketua Asosiasi Perikanan Provinsi Songkhla, Thailand, mengungkapkan terdapat setidaknya 300 kapal Thailand yang melakukan pencurian ikan di perairan Indonesia sebelum keputusan moratorium dikeluarkan Menteri Susi. Menurut mereka, nelayan-nelayan yang melakukan kegiatan ilegal tersebut menggunakan nama Indonesia di kapalkapal mereka sehingga membuat nelayan Thailand enggan dipersalahkan dalam tuduhan kegiatan illegal fishing. Kemudian baik Pemerintah Thailand maupun Pemerintah Indonesia menemukan solusi yaitu dengan menyepakati pembentukan Kelompok Kerja dalam rangka menangani kasus yang mengancam keamanan perairan yang dalam hal ini berupa pencurian ikan. Selain itu kedua negara juga sepakat untuk memberikan sanksi berupa hukum yang dituduh terlibat dalam kegiatan illegal fishing.

Selanjutnya negara yang juga menyatakan bahwa mereka keberatan dengan kebijakan ini, yaitu Malaysia. Malaysia menyayangkan atas ditangkapnya nelayan-nelayan yang terbukti melakukan illegal fishing daripada memulangkan mereka. Hal itu, bagi Malaysia, sudah termasuk pelanggaran hukum. Padahal, pemulangan nelayan hanya berlaku di wilayah yang statusnya masih belum jelas milik siapa. Kedubes Malaysia di Jakarta menunjukkan sikap yang lebih mengakui serta menghormati tindakan Indonesia dalam hal penembakan dan penenggelaman kapal-kapal yang terbukti melakukan pelanggaran. Sikap yang demikian itulah merepresentasikan secara resmi sikap Pemerintah Malaysia terhadap Pemerintah Joko Widodo dalam hal penegakan 
hukum di laut, yang merupakan bagian dari upaya mewujudkan Indonesia sebagai Poros Maritim Dunia.

\section{Penutup}

Tidak dapat dipungkiri bahwa abad ke-21 ini memunculkan tantangan sekaligus peluang bagi hubungan internasional. Ini menyebabkan negara-negara di seluruh dunia termasuk Indonesia bersaing dari berbagai aspek supaya tidak tertinggal dalam dinamika politik yang selalu berubahubah. Terpilihnya Presiden Jokowi serta kebijakan inward looking yang lebih memprioritaskan pembangunan dalam negeri merupakan langkah awal mengembalikan identitas Indonesia sebagai bangsa maritim. Meskipun dalam prosesnya, tentu saja Indonesia menghadapi ancaman keamanan yang berpotensi terjadi di laut dan tidak dapat diabaikan begitu saja oleh Indonesia. Sudah sepatutnya Indonesia sebagai pemimpin dari ASEAN berinisatif untuk mengatasi segala ancaman di bidang maritim demi terwujudnya bangsa maritim yang berdaulat bagi kawasan Indo-Pasifik. Penelitian ini dimaksudkan untuk mengetahui faktor internal dan eksternal Indonesia mengajukan perjanjian Indo-Pasifik sekaligus juga membahas perubahan politik Indonesia yang setelah era Soekarno berakhir berorientasi pada darat hingga era pemerintahan Susilo Bambang Yudhoyono serta bagaimana posisi strategis Indonesia membuat Indonesia mengeluarkan geopolitik Poros Maritim Dunia.

Melalui penelitian ini, terdapat temuan dari argumen konsep yang sudah dijelaskan di bab sebelumnya yaitu, antara lain: Pertama, adanya faktor internal dan eksternal digagasnya perjanjian Indo-Pasifik yang erat kaitannya dengan perubahan politik luar negeri. Karena dinamika politik yang selalu berubah-ubah menyesuaikan zaman, maka perlu adanya solusi yang memadai dalam artian membuat kebijakan yang lebih modern dan mampu menyelesaikan permasalahan yang ada yang merujuk dari faktor internal dan eksternal tersebut. Kedua, Poros Maritim Dunia dan hubungannya dengan determinan domestik. Sejalan dengan apa yang dikemukakan Lentner mengenai determinan domestik yang mengacu pada kondisi geografis, Poros Maritim Dunia lahir sebagai geopolitik Indonesia yang letaknya strategis di Indo-Pasifik dimana Indonesia berada tepat di tengah-tengah antara samudera Hindia dan samudera Pasifik. Letak Indonesia yang strategis ini, ditambah dengan kekayaan sumber daya alam lautnya, membuat negara se-kawasan maupun negara-negara luar kawasan tertarik. Oleh karena itu sebagai negara yang memiliki 
kendali atas sebagian besar perairan di Asia Tenggara, Indonesia harus bisa memanfaatkan penuh lautnya demi mewujudkan negara maritim yang berdaulat tanpa campur tangan pihak luar.

\section{Daftar Pustaka}

Agastia, I. G., \& Perwita, A. A. (2016). Indonesia's Maritime Axis and The Security of Sea Lanes of Communications (SLOCs) in the Indo-Pacific. doi:10.18196/hi.2016.0081.1021

Agastia, I. G., \& Perwita, A. A. (2018). Building Maritime Domain Awareness as an Essential Element of The Global Maritime Fulcrum: Challenges and Prospects for Indonesia's Maritime Security. doi:10.18196/hi.61109

Alvian, R. A., Putri, G. C., \& Ardhani, I. (2018, Maret 29). Haluan Baru Politik Luar Negeri Indonesia: Perbandingan Diplomasi ‘Middle Power' Susilo Bambang Yudhoyono dan Joko Widodo. Dipetik Juli 15, 2019

Amaliyah, N. (2015). Kebijakan Politik Luar Negeri Indonesia di bawah Pemerintahan Presiden Jokowi. Dipetik Juli 16, 2019

Andika, M. T. (2016). An Analysis of Indonesia Foreign Policy Under Jokowi's Pro-People Diplomacy. Dipetik Juli 12, 2019

Anggraeni, P. S. (2016). Politik Luar Negeri Indonesia Poros Maritim Dunia di Era Pemerintahan Joko Widodo.

China to increase overseas military bases: Pentagon report. (2019, Mei 3). Diambil kembali dari Al Jazeera: https://www.aljazeera.com/news/2019/05/china-increase-overseas-militarybases-pentagon-report-190503065146243.html

Cina Pertanyakan Konsep Indo-Pasifik ASEAN. (2019, Januari 24). Dipetik Juli 4, 2019, dari ANTARANEWS.com: https://www.antaranews.com/berita/791142/china-pertanyakankonsep-indo-pasifik-asean

Darmastuti, S., \& Subekti, E. F. (2015). Tantangan Diplomasi Maritim Indonesia Menuju Poros Maritim Dunia. Dipetik Maret 19, 2019 
Delanova, M. O. (2017). Politik Luar Negeri Indonesia Pada Masa Pemerintahan Presiden Joko Widodo Melalui Penguatan Diplomasi Ekonomi. Dinamika Global. Dipetik Juli 23, 2019

Febrina. (2014). Perbedaan Pandangan Jepang dan Cina Terhadap Kepulauan Senkaku Dalam Perjanjian San Fransisco 1951. Dipetik Maret 18, 2019

Hanim, L., \& Noorman, M. S. (2017). Kebijakan Kelautan Dalam Rangka Menjaga dan Mengelola Sumber Daya Alam Laut Sebagai Upaya Mewujudkan Indonesia Sebagai Poros Maritim Dunia. Dipetik Juli 31, 2019

Haryanto, A. (2017). Indonesia dan Jerman Sepakati Kerja Sama di Bidang Maritim. Dipetik Agustus 6, 2019, dari Tirto.id: https://tirto.id/indonesia-dan-jerman-sepakati-kerja-samadi-bidang-maritim-cpMz

Indonesia Ajak Australia Terus Jaga Stabilitas dan Keamanan di Indo-Pasifik. (2019, Mei 4). Dipetik Juli 3, 2019, dari KEMENTRIAN LUAR NEGERI INDONESIA: https://kemlu.go.id/portal/id/read/236/berita/indonesia-ajak-australia-terus-jaga-stabilitasdan-keamanan-di-indo-pasifik

Indonesia Diharapkan Menjadi Penggerak Indo-Pasifik. (2018, Juni 6). Dipetik Maret 13, 2019, dari CNN Indonesia: https://www.cnnindonesia.com/internasional/20180605140055-106303615/indonesia-diharapkan-menjadi-penggerak-indo-pasifik

Indonesia Dorong Kerja Sama Maritim ASEAN-India di Kawasan Indo-Pasifik. (2019, April 12). Dipetik Juli 3, 2019, dari KEMENTRIAN LUAR NEGERI REPUBLIK INDONESIA: https://kemlu.go.id/portal/id/read/188/berita/indonesia-dorong-kerja-sama-maritim-aseanindia-di-kawasan-indo-pasifik

Indonesia Inisiasi Kerja Sama Antar Negara Kepulauan dan Negara Pulau. (2017). Dipetik Agustus 6, 2019, dari Kemenko Kemaritiman RI: https://maritim.go.id/indonesia-inisiasikerja-sama-antar-negara-kepulauan-dan-negara-pulau/

Indonesia-Thailand Dorong Pengembangan Konsep Indo-Pasifik ASEAN. (2019, Maret 13). Dipetik Juli 3, 2019, dari ANTARANEWS.com: https://www.antaranews.com/berita/809215/indonesia-thailand-dorong-pengembangankonsep-indo-pasifik-asean 
Irawan, S. (2018). Diskursus Indo-Pasifik: Hegemoni Amerika, Persaingan Strategis, Hingga Transformasi Geopolitik Kawasan. MANDALA. Dipetik Juli 4, 2019

Jokowi Perkenalkan Konsep Indo-Pasifik di KTT ASEAN-India. (2018, Januari 26). Dipetik Maret 13, 2019, dari CNN Indonesia: https://www.cnnindonesia.com/internasional/20180126074522-113-271697/jokowiperkenalkan-konsep-indo-pasifik-di-ktt-asean-india

Kerjasama AS-Indonesia di Bidang Maritim. (2015). Dipetik Agustus 6, 2019, dari Kedutaan Besar dan Konsulat AS di Indonesia: https://id.usembassy.gov/id/kerjasama-as-indonesiadi-bidang-maritim/

Maksum, A. (2015, Mei). Poros Maritim dan Politik Luar Negeri Jokowi. Andalas Journal of International Studies, 4. Dipetik Agustus 20, 2019

Manurung, H. (2018). Menuju Poros Maritim Dunia: Masa Depan Indonesia. Dipetik Juli 26, 2019

Mardiastuti, A. (2018). Ini 9 Poin Kerja Sama Maritim Indonesia-Australia. Dipetik Agustus 6, 2019, dari detikNews: https://news.detik.com/berita/d-3919793/ini-9-poin-kerja-samamaritim-indonesia-australia

Mas'oed, M. (1990). Ilmu Hubungan Internasional: Disiplin dan Metodologi. Jakarta: LP3ES.

Menlu sebut konsep Indo-Pasifik disepakati ASEAN. (2018, November 13). Dipetik Juli 3, 2019, dari ANTARANEWS.com: https://www.antaranews.com/berita/767998/menlu-sebutkonsep-indo-pasifik-disepakati-asean

Menuju Poros Maritim Dunia. (2016, Oktober 18). Diambil kembali dari Kementrian Komunikasi dan Informatika Republik Indonesia: https://www.kominfo.go.id/content/detail/8231/menuju-poros-maritimdunia/0/kerja_nyata

Montratama, I. (2016). Rekonstruksi Politik Luar Negeri Indonesia Di Tengah Dinamika Lingkungan Strategis Indo-Pasifik Abad Ke-21. doi:10.24198/intermestic.v1n1.4 
Nainggolan, P. P. (2015). Kebijakan Poros Maritim Dunia Joko Widodo dan Implikasi Internasionalnya. Dipetik Juli 25, 2019

Natalegawa, M. (2013). An Indonesian Perspective on Indo-Pacific. Dipetik Juni 22, 2019

Perkenalkan Konsep Indo-Pasifik, Indonesia Set the Tone di East Asia Summit. (2018, Agustus

6). Dipetik Maret 13, 2019, dari Kementrian Luar Negeri Republik Indonesia:

https://www.kemlu.go.id/id/berita/Pages/Perkenalkan-Konsep-Indo-Pasifik,-Indonesia-

Set-the-Tone-di-East-Asia-Summit-.aspx

Purnama, A. C. (2017). Gagasan Indonesia Mengenai Indo-Pacific Treaty: Prospek dan Masalah. Dipetik November 30, 2018

Ram, V. (2015). The Proposal for an Indo-Pacific Treaty of Friendship and Cooperation: A Critical Reassessment. Dipetik Maret 13, 2019

Situmorang, M. (2015). Orientasi Kebijakan Politik Luar Negeri Indonesia di bawah Pemerintahan Jokowi-JK. Dipetik Juli 15, 2019

Sudira, I. N. (2014). Konflik Laut Cina Selatan dan Politik Luar Negeri Indonesia ke Amerika dan Eropa.

Suryadinata, L. (2018). Indonesia and its Stance on the "Indo-Pacific".

Syahrin, M. N. (2018). Kebijakan Poros Maritim Jokowi dan Sinergitas Strategi Ekonomi dan Keamanan Laut Indonesia. Dipetik Juli 27, 2019

Tene, R. M. (2019, April 10). Indonesia dan Indo-Pasifik. KOMPAS.

Widiatmaja, A., \& Albab, U. (2019). Indonesia di Era Susilo Bambang Yudhoyono (SBY) dan Joko Widodo: Kebijakan Luar Negeri di Tengah Dinamika Lingkungan Strategis Regional. Dipetik Juli 22, 2019

Wijaya, C., \& Marta, D. (2019, Mei 4). Menteri Susi kembali tenggelamkan kapal: 'Ini way out yang sangat cantik untuk bangsa kita, menakutkan untuk bangsa lainnya'. Dipetik Juli 23, 2019, dari BBC: https://www.bbc.com/indonesia/indonesia-48131222

Wirasenjaya, A. M. (2018). From State-Led Regionalism to Multi-track Regionalism. The 6th Asian Academic Society International Conference (AASIC). Dipetik Oktober 14, 2019 
Wuryandari, G. (2016). Politik Luar Negeri Indonesia: Refleksi dan Prediksi 10 Tahun. Dipetik April 7, 2019

Yani, Y. M. (2009). Change and Continuity In Indonesian Foreign Policy. Dipetik April 11, 2019

Yani, Y. M. (2017). Perspektif-Perspektif Politik Luar Negeri: Teori dan Praksis. Dipetik Juli 10, 2019

Yani, Y. M., \& Montratama, I. (2015, Agustus). Indonesia Sebagai Poros Maritim Dunia: Suatu Tinjauan Geopolitik. Dipetik Agustus 18, 2019 